\title{
ANALISIS PENGARUH PAJAK DAERAH, RETRIBUSI DAERAH TERHADAP TENAGA KERJA DAN PERTUMBUHAN EKONOMI DI KOTA PALANGKA RAYA PROVINSI KALIMANTAN TENGAH
}

\author{
Ju Kumala Dewi ${ }^{1}$ \\ Made Kembar Sri Budhi ${ }^{2}$ \\ ${ }^{1}$ Fakultas Ekonomi dan Bisnis Universitas Udayana (Unud), Bali, Indonesia \\ ${ }^{1}$ E-mail: ju.kumaladewi.08@gmail.com \\ ${ }^{2}$ Fakultas Ekonomi dan Bisnis Universitas Udayana (Unud), Bali, Indonesia
}

\begin{abstract}
ABSTRAK
Tujuan penelitian ini adalah untuk menganalisis pengaruh langsung pajak daerah dan retribusi daerah terhadap penyerapan tenaga kerja, menganalisis pengaruh langsung pajak daerah, retribusi daerah, penyerapan tenaga kerja terhadap pertumbuhan ekonomi dan menganalisis pengaruh tidak langsung pajak daerah, retribusi daerah terhadap pertumbuhan ekonomi melalui penyerapan tenaga kerja. Sampel penelitian yang digunakan yaitu Kota Palangka Raya. Data sekunder digunakan didapat dari Dinas Pendapatan, data penyerapan tenaga kerja yang diperoleh dari Dinas Tenaga Kerja dan Transmigrasi serta data pertumbuhan ekonomi yang diperoleh dari Badan Pusat Statistik di Kota Palangka Raya pada tahun 1996-2016. Pengujian menggunakan teknik analisis jalur dengan aplikasi SPSS 21. Hasil pengujian dalam penelitian ini menunjukkan: 1) Pajak daerah dan retribusi daerah berpengaruh positif dan signifikan terhadap penyerapan tenaga kerja; 2) Pajak daerah berpengaruh positif dan signifikan terhadap pertumbuhan ekonomi; retribusi daerah tidak berpengaruh terhadap pertumbuhan ekonomi dan tenaga kerja tidak berpengaruh terhadap Pertumbuhan Ekonomi; dan 3) Hasil pengujian pengaruh tidak langsung menunjukkan Tenaga Kerja tidak mampu memediasi variabel Pajak Daerah dan Retribusi Daerah pada Pertumbuhan Ekonomi.
\end{abstract}

Kata Kunci: Pajak Daerah, Retribusi Daerah, Tenaga Kerja, Pertumbuhan Ekonomi

\begin{abstract}
This study aims to analyze direct influence of local taxes and levies on the absorption of labor, to analyze the direct influence of local taxes, levies, employment to economic growth and to analyze the indirect effect of local taxes, regional levies on economic growth through employment.The research sample used in this research is Kota Palangka Raya. Secondary data used in this study were obtained from the Revenue Service, employment data obtained from the Office of Manpower and Transmigration as well as data on economic growth based on 2000 constant prices obtained from the Central Bureau of Statistics in Kota Palangka Raya from 1996-2016.Testing data in this study using path analysis techniques with the help of SPSS 21 applications. The results of testing direct influence in this study indicate 1) Local taxes and user charges affect the workforce ; 2) Local taxes have an effect on economic growth while regional levy has no effect on labor; and 3) The result of indirect effect test indicates that the workforce is not able to mediate local tax variables and regional levies on economic growth.
\end{abstract}

Keywords: Local Tax, Regional Retribution, Labor, Economic Growth 
Ju Kumala Dewi dan Made Kembar Sri Budhi. Analisis Pengaruh Pajak Daerah...

\section{PENDAHULUAN}

Pembangunan nasional di Indonesia merupakan rencana strategis yang diarahkan untuk mengembangkan potensi daerah masing-masing dengan menyeimbangkan laju pertumbuhan antar daerah di Indonesia sesuai prioritasnya dalam meningkatkan pendayagunaan dan potensi daerah secara optimal. UndangUndang Nomor 23 Tahun 2014 tentang Pemerintahan Daerah adalah salah satu landasan yuridis bagi pengembangan otonomi daerah di Indonesia.

Pada era otonomi daerah, pemerintah daerah diberi kewenangan untuk membuat kebijakan yang disesuaikan dengan kondisi daerah, salah satu usaha dalam mewujudkan kemandirian suatu daerah dengan menggali sumber penerimaan daerah melalui pajak daerah, retribusi daerah, laba usaha daerah dan pendapatan daerah lainnya yang sah. Pajak daerah merupakan iuran wajib yang dipaksakan berdasarkan peraturan perundang-undangan yang berlaku, mengingat ini sebagai kewajiban masyarakat/wajib pajak. Tujuan dari kebijakan otonomi daerah dan desentralisasi fiskal di tingkat daerah memberikan pelayanan yang lebih efisien, cepat dan efektif. Asumsinya pemerintah kabupaten dan kota memiliki pemahaman yang lebih baik mengenai kebutuhan dan aspirasi masyarakat (Kuncoro, 2004). Pemerintah Daerah Kota Palangka Raya dituntut untuk meningkatkan potensi sumber-sumber penerimaan daerah yang mengacu kepada aturan dan ditetapkan sesuai dengan Undang-undang Nomor 18 Tahun 1997 tentang Pajak Daerah dan Retribusi Daerah, 
dalam hal ini dapat diketahui melalui perkembangan dan pertumbuhan pembangunan penerimaan Pendapatan Asli Daerah Kota Palangka Raya pada Tabel 1.

Tabel 1

Pendapatan Pemerintah Kota Palangka Raya Tahun 2016

(Dalam Juta Rupiah)

\begin{tabular}{|c|c|c|c|c|c|}
\hline $\begin{array}{c}\text { Jenis Pendapatan } \\
\text { Daerah }\end{array}$ & Target & Realisasi & $\begin{array}{l}\text { Tungg } \\
\text { akan }\end{array}$ & $\begin{array}{l}\text { Tungg- } \\
\text { akan } \\
(\%)\end{array}$ & $\begin{array}{c}\text { Realia- } \\
\text { asi } \\
(\%)\end{array}$ \\
\hline $\begin{array}{l}\text { 1. Penerimaan } \\
\text { Daerah }\end{array}$ & $125.922,1$ & $118.758,2$ & $7.163,8$ & 5,68 & 94,32 \\
\hline 1.1 Pajak Daerah & $80.630,0$ & $82.047,6$ & 0 & 0 & 100 \\
\hline 1.2 Retribusi Daerah & $15.175,1$ & $14.616,7$ & 558,4 & 3,68 & 96,32 \\
\hline $\begin{array}{l}\text { 1.3 Hasil Perusahaan } \\
\text { Milik Daerah dan } \\
\text { Pengelolaan } \\
\text { Kekayaan } \\
\text { Daerah Yang } \\
\text { Dipisahkan }\end{array}$ & 60,0 & 60,0 & 0 & 0 & 100 \\
\hline $\begin{array}{l}\text { 1.4 Lain-Lain PAD } \\
\text { Yang Sah }\end{array}$ & $30.056,9$ & $22.033,9$ & $8.023,7$ & 26,70 & 73,30 \\
\hline $\begin{array}{l}\text { 2. Dana } \\
\text { Perimbangan }\end{array}$ & 1.014.566,1 & $826.834,3$ & 187,7 & 18,50 & 81,49 \\
\hline 2.1 Bagi Hasil Pajak & $69.572,9$ & $61.549,2$ & 8,0 & 1,16 & 98,84 \\
\hline $\begin{array}{l}\text { 2.2 Dana Alokasi } \\
\text { Umum }\end{array}$ & $657.826,4$ & $657.826,4$ & 0 & 0 & 100 \\
\hline $\begin{array}{l}\text { 2.3 Dana Alokasi } \\
\text { Khusus }\end{array}$ & $100.701,7$ & $82.298,8$ & 18,4 & 18,27 & 81,73 \\
\hline $\begin{array}{l}\text { 3. Lain-Lain } \\
\text { Pendapatan } \\
\text { Yang Sah }\end{array}$ & 189.918,6 & 172.026,1 & 17,8 & 9,43 & 90,57 \\
\hline $\begin{array}{l}\text { 3.1 Pendapatan } \\
\text { Hibah }\end{array}$ & $3.000,0$ & $3.000,0$ & 0 & 0 & 100 \\
\hline $\begin{array}{l}\text { 3.2 Dana Bagi Hasil } \\
\text { Pajak Dari } \\
\text { Provinsi Dan } \\
\text { Pemerintah } \\
\text { Daerah Lainnya }\end{array}$ & $84.094,4$ & $67.732,3$ & 16,3 & 19,46 & 80,54 \\
\hline $\begin{array}{l}\text { 3.3 Dana } \\
\text { Penyesuaian Dan } \\
\text { Otonomi Khusus }\end{array}$ & $102.824,2$ & $101.293,8$ & 1,5 & 1,49 & 98,51 \\
\hline
\end{tabular}

Sumber: Dinas Pendapatan Daerah Kota Palangka Raya, 2017 
Ju Kumala Dewi dan Made Kembar Sri Budhi. Analisis Pengaruh Pajak Daerah...

Berdasarkan Tabel 1, target penerimaan daerah terhadap Pendapatan Asli Daerah di Kota Palangka Raya pada tahun 2016 sebesar Rp. 125.922,1 Juta Rupiah sedangkan yang terealisasi sebesar Rp. 118.758,2 Juta Rupiah nilainya tidak mencapai target PAD yang ditentukan disini terlihat tunggakan yang terjadi sebesar Rp. 7.163,8 Juta Rupiah dengan persentasi sebesar 5,68 \% sedangkan realisasi PAD sebesar 94,32 \%. Namun, realisasi pajak daerah yang terjadi menunjukkan nilai sebesar Rp. 82.047,6 Juta Rupiah mengalami peningkatan dari target sebesar Rp. 80.630,0 Juta Rupiah yang telah ditentukan dan realisasi yang terjadi sebesar $100 \%$, meskipun hal yang sebaliknya terjadi pada poin retribusi daerah yang jumlahnya sebesar Rp. 14.616,7 tidak memenuhi target yang ditentukan sebesar 15.175,1 Juta Rupiah disini terjadi tunggakan retribusi daerah sebesar 558,4 Juta Rupiah dengan persentasi tunggakan sebesar 3,68 \% dan realisasi dari penerimaan retribusi daerah sebesar 96,32 \%. Berdasarkan Tabel 1 dapat diketahui bahwa pada poin-poin realisasi jenis pendapatan daerah cenderung fluktuatif. Hal ini mengindikasikan bahwa Kota Palangka Raya belum secara optimal mengelola pendapatan asli daerahnya. Padahal Kota Palangka Raya sebagai Ibu Kota Provinsi Kalimantan Tengah yang mana posisinya berada di tengah yang memiliki potensi dalam bidang jasa, perdagangan dan pariwisata akan mendorong percepatan pembangunan ekonomi di daerah Kota Palangka Raya

Apabila dicermati bahwa pelaksanaan pembangunan nasional maupun pembangunan di daerah telah memberi sumbangsih dalam menghasilkan perkembangan yang pesat dalam kehidupan nasional dan daerah, khususnya di bidang 


\section{E-Jurnal Ekonomi dan Bisnis Universitas Udayana 7.6 (2018): 1695-1722}

ekonomi. Pesatnya perkembangan sosial ekonomi sebagai hasil dari pembangunan daerah menghendaki adanya kerjasama di antara pemerintah, sektor swasta (private sector) dan masyarakat untuk mengelola sumber daya di Kota Palangka Raya dalam upaya peningkatan pertumbuhan ekonomi dan lapangan kerja. Peran pembangunan sebagai acuan untuk mengurangi ketimpangan yang terjadi di dalam distribusi pendapatan penduduk dan wilayah, yang mana diketahui bahwa pertumbuhan ekonomi wilayah adalah pertumbuhan pendapatan masyarakat di daerah.

Penerimaan sumber Pendapatan Asli Daerah menopang seluruh aktivitas kegiatan perekonomian masyarakat menjadi program pemerintah daerah dalam upaya peningkatan dan kemajuan dalam mensejahterakan masyarakat yang makin bertambah tinggi. Dalam kenyataannya banyak fenomena dan masalah yang timbul di dalam pertumbuhan ekonomi wilayah, tak terkecuali di wilayah Kota Palangka Raya. Hal ini mengingat pertumbuhan ekonomi yang cepat berdampak terhadap ketimpangan dalam distribusi pendapatan. Kesenjangan dan ketimpangan di wilayah Kota Palangka Raya dan pemerataan pembangunan menjadi permasalahan utama penyebab tingkat kemiskinan. Untuk melihat pertumbuhan ekonomi di suatu wilayah maka kenaikan PDRB dijadikan acuan tanpa memandang apakah kenaikan itu lebih besar atau kecil dari tingkat pertumbuhan penduduk, sebagaimana Tabel 1.2 yang menunjukan pertumbuhan ekonomi di Kota Palangka Raya adalah sebagai berikut. 
Ju Kumala Dewi dan Made Kembar Sri Budhi. Analisis Pengaruh Pajak Daerah...

Tabel 2

Produk Domestik Regional Bruto Atas Dasar Harga Konstan 2000 Menurut Lapangan Usaha Kota Palangka Raya Tahun 2016 (Dalam Juta Rupiah)

\begin{tabular}{lcc}
\hline \multicolumn{1}{c}{ Lapangan Usaha } & Jumlah & $\mathbf{( \% )}$ \\
\hline A. Pertanian, Kehutanan, dan Perikanan & $232.921,4$ & 2,71 \\
B. Pertambangan dan Penggalian & $109.357,2$ & 1,29 \\
C. Industri Pengolahan & $911.077,8$ & 10,96 \\
D. Pengadaan Listrik dan Gas & $31.797,7$ & 0,30 \\
E. Pengadaan Air, Pengelolaan Sampah, & $16.404,0$ & 0,19 \\
$\quad$ Limbah dan Daur Ulang & & \\
F. Konstruksi & $976.962,2$ & 11,38 \\
G. Perdagangan Besar Dan Eceran; Reparasi & $1.613 .754,3$ & 17,36 \\
$\quad$ Mobil dan Sepeda Motor & & \\
H. Transportasi dan Pergudangan & $740.170,3$ & 8,40 \\
I. Penyediaan Akomodasi dan Makan Minum & $416.537,0$ & 4,89 \\
J. Informasi dan Komunikasi & $175.739,4$ & 1,47 \\
K. Jasa Keuangan Dan Asuransi & $670.776,9$ & 7,08 \\
L. Real Estate & $279.320,5$ & 3,06 \\
M,N Jasa Perusahaan & $6.465,7$ & 0,07 \\
O. Adminstrasi Pemerintahan, Pertahanan dan & $1.881 .129,0$ & 21,80 \\
$\quad$ Jaminan Sosial Wajib & & \\
P. Jasa Pendidikan & $485.724,5$ & 5,54 \\
Q. Jasa Kesehatan dan Kegiatan Sosial & $201.156,1$ & 2,31 \\
R,S Jasa Lainnya & $110.254,2$ & 1,21 \\
T,U Services & & \\
& & \\
\hline
\end{tabular}

Sumber: Kota Palangka Raya Dalam Angka 2017, BPS Kota Palangka Raya

Lajunya pertumbuhan ekonomi di daerah dihitung berdasarkan perubahan

PDRB atas dasar harga konstan tahun yang bersangkutan terhadap tahun sebelumnya yang merupakan indikator makro untuk melihat perekonomian secara riil di suatu wilayah. Tabel 2 menunjukan kinerja perekonomian di Kota Palangka Raya selama periode tahun 2016 bahwa sektor barang maupun jasa tidak berada pada urutan pertama dengan nilai terbesar berdasarkan harga konstan 2000. 
Umumnya faktor yang berpengaruh pada pertumbuhan ekonomi adalah sumber daya manusia. Sebagaimana diketahui bahwa selain pajak daerah dan retribusi daerah sebagai sumber penerimaan Pendapatan Asli Daerah, maka sektor tenaga kerja juga mempengaruhi pertumbuhan ekonomi yang ada di Kota Palangka Raya. Todaro (2000) menjelaskan pertumbuhan angkatan kerja secara tradisional dianggap memacu pertumbuhan ekonomi dan terjadi penambahan tingkat produksi pada Tabel 3 .

Tabel 3

Tenaga Kerja di Kota Palangka Raya Povinsi Kalimantan Tengah Tahun 2016 (Orang)

\begin{tabular}{|c|c|c|c|c|}
\hline \multirow{2}{*}{$\begin{array}{c}\text { Kegiatan Utama/ } \\
\text { Main Activity }\end{array}$} & \multicolumn{2}{|c|}{ Jenis Kelamin } & \multirow[b]{2}{*}{$\begin{array}{c}\text { Jumlah/ } \\
\text { Total }\end{array}$} & \multirow[b]{2}{*}{$(\%)$} \\
\hline & $\begin{array}{c}\text { Laki- } \\
\text { Laki/Male }\end{array}$ & $\begin{array}{l}\text { Perempuan/ } \\
\text { Female }\end{array}$ & & \\
\hline $\begin{array}{l}\text { 1. Angkatan Kerja } \\
\text { Economically Actice }\end{array}$ & 78. 081 & 49.551 & 127.632 & 65,72 \\
\hline 1. Bekerja/Working & 71.622 & 46.967 & 119.589 & \\
\hline $\begin{array}{l}\text { 2. Pengangguran } \\
\text { Terbuka/Unemp- } \\
\text { loyment }\end{array}$ & 5.459 & 2.584 & 8.043 & \\
\hline $\begin{array}{l}\text { 2. Bukan Angkatan Kerja } \\
\text { Economically Inactive }\end{array}$ & 21.308 & 45.272 & 66.580 & 34,28 \\
\hline 1. Sekolah/School & 15.010 & 14.509 & 29.519 & \\
\hline $\begin{array}{l}\text { 2. Mengurus Rumah } \\
\text { Tangga/House-keepig }\end{array}$ & 5.166 & 29.604 & 34.770 & \\
\hline $\begin{array}{l}\text { 3. Lainnya/Others } \\
\text { Jumlah/Total }\end{array}$ & $\begin{array}{c}1.132 \\
99.389\end{array}$ & $\begin{array}{c}1.159 \\
\mathbf{9 4 . 8 2 3}\end{array}$ & $\begin{array}{c}2.291 \\
\mathbf{1 9 4 . 2 1 2}\end{array}$ & 100 \\
\hline
\end{tabular}

Sumber: Dinas Tenaga Kerja Kota Palangka Raya, 2017

Berdasarkan Tabel 3 terlihat bahwa tenaga kerja di Kota Palangka Raya bervariasi jumlahnya. Angkatan kerja yang bekerja memiliki jumlah tertinggi yaitu 119.589 orang. Sedangkan, jumlah angkatan kerja pengangguran terbuka yang belum 
Ju Kumala Dewi dan Made Kembar Sri Budhi. Analisis Pengaruh Pajak Daerah...

bekerja pada tahun 2016 sebesar 8.043 orang. Jenis tenaga kerja yaitu bukan angkatan kerja pada Tabel 3 di atas memiliki jumlah yang lebih kecil dibanding angkatan kerja yaitu 66.580 orang. Data tersebut menjelaskan bahwa setengah dari jumlah angkatan kerja masih belum memiliki pekerjaan dan tidak produktif.

Pada Tabel 3 di atas mengindikasikan bahwa pemerintah daerah Kota Palangka Raya belum maksimal memberikan ketersediaan lapangan kerja baru pada penyerapan tenaga kerja baru setiap tahunnya. Terkait ketenagakerjaan tersebut permasalahan yang terjadi di Kota Palangka Raya terlihat dari persentase untuk jumlah angkatan kerja sebesar 65,72\% sedangkan bukan angkatan kerja lebih rendah daripada jumlah angkatan kerja sebesar 34,28 \%, disini terjadi selisih sebesar 31,44 \%. Hal ini menunjukkan kondisi ketenagakerjaan yang ada di Kota Palangka Raya adalah daerah yang masih dalam tahap perkembangan yang dalam hal ini masih mengalami pembenahan baik dalam pembangunan ekonomi daerah maupun pembangunan sumber daya manusia yang berkualitas guna mewujudkan kesejahteraan masyarakat yang adil dan makmur. Kondisi yang demikian apabila dibiarkan tentu dapat semakin meningkat sehingga diperlukan dan harus dilakukan langkah-langkah strategis yang cepat dan tepat oleh pemerintah Kota Palangka Raya untuk mengatasinya. Berdasarkan isu dan fenomena di atas, disusunlah pertanyaan penelitian yaitu: 1). Bagaimanakah pengaruh langsung Pajak Daerah dan Retribusi Daerah terhadap Penyerapan Tenaga Kerja di Kota Palangka Raya Provinsi Kalimantan Tengah? 2). Bagaimanakah pengaruh langsung Pajak Daerah, Retribusi Daerah dan Penyerapan Tenaga Kerja terhadap Pertumbuhan Ekonomi di Kota 


\section{E-Jurnal Ekonomi dan Bisnis Universitas Udayana 7.6 (2018): 1695-1722}

Palangka Raya Provinsi Kalimantan Tengah? 3). Bagaimanakah pengaruh tidak langsung Pajak Daerah, Retribusi Daerah terhadap Pertumbuhan Ekonomi melalui Penyerapan Tenaga Kerja di Kota Palangka Raya Provinsi Kalimantan Tengah?

Manfaat teoretis dari penelitian ini yaitu dapat dijadikan bahan kajian lebih lanjut serta memperkaya penggunaan alat analisis penelitian dan diharapkan dapat memberikan masukan informasi dan pertimbangan kepada pihak-pihak terkait (Stakeholder), para pemegang kebijakan saat menentukan kebijakan di daerah sehingga dapat meningkatkan kinerja pemerintah daerah dalam upaya menseejahterakan masyarakat.

\section{LANDASAN TEORETIS}

Dalam usaha memperbesar peran pemerintah daerah di pembangunan, pemerintah daerah dituntut lebih mandiri untuk membiayai kegiatan operasional rumah tangganya. Berdasarkan hal ini maka penerimaan pendapatan daerah tidak dapat dipisahkan dari belanja daerah, karena saling keterkaitannya antara alokasi anggaran yang disusun dan dibuat dalam melancarkan roda pemerintahan. Sedangkan Halim (2007 : 23) mendefinisikan bahwa keuangan daerah adalah semua hak dan kewajiban yang dinilai dengan uang maupun barang yang dijadikan kekayaan daerah sepanjang belum dimiliki dan dikuasai oleh Negara atau daerah sesuai ketentuan/peraturan perundangan yang berlaku. 
Ju Kumala Dewi dan Made Kembar Sri Budhi. Analisis Pengaruh Pajak Daerah...

Pada Undang-undang No. 34 Tahun 2000 dijelaskan pajak itu wajib namun siapapun yang dikenakan pajak tidak bebas memilih apakah harus membayar atau tidak. Salah satu pengertian pajak sebagaimana pendapat Mangkoesoebroto (1991), yang berupa pungutan hak preogratif yang dilakukan pemerintah sesuai Undangundang, pemungutannya dapat dipaksakan pada wajib pajak tanpa ada balas jasa langsung penggunaannya dan digunakan untuk membiayai penyelenggaraan pemerintah daerah dan pembangunan daerah". Sedangkan bunyi Undang-Undang Nomor 28 Tahun 2009 Pasal 1 angka 10 tentang Pajak Daerah dan Retribusi Daerah adalah sebagai berikut:

"Pajak Daerah, yang selanjutnya disebut Pajak, adalah kontribusi wajib kepada Daerah yang terutang oleh orang pribadi atau badan yang bersifat memaksa berdasarkan Undang-Undang, dengan tidak mendapatkan imbalan secara langsung dan digunakan untuk keperluan Daerah bagi sebesarbesarnya kemakmuran rakyat".

Selain itu, menurut Suandy (2002) menjelaskan bahwa Pajak daerah adalah pajak yang wewenang pemungutannya ada pada Pemerintah Daerah yang pelaksanaannya dilakukan oleh Dinas Pendapatan Daerah. Sedangkan pengertian retribusi daerah menurut Ilyas \& Burton (2007), definisi retribusi adalah:

a. Pungutan retribusi berdasarkan undang-undang berlaku;

b. Sifat pungutannya dipaksakan;

c. Pemungutannya oleh Negara;

d. Digunakan bagi masyarakat umum;

e. Kontra-prestasi yang dirasakan pembayar retribusi.

Pungutan retribusi umumnya diberikan atas pembayaran jasa atau pemberian izin yang disediakan atau diberikan oleh pemerintah kepada setiap orang atau badan. 


\section{E-Jurnal Ekonomi dan Bisnis Universitas Udayana 7.6 (2018): 1695-1722}

Sebagaimana penjelasan dalam Ilyas \& Burton (2007), bahwa kontra-prestasinya langsung dapat dirasakan, maka sifat paksaannya bersifat ekonomis. Artinya, apabila seseorang atau badan tidak mau membayar retribusi maka manfaat ekonominya dapat dirasakan langsung oleh pembayar retribusi. Menurut Mahmudi (2010) menjelaskan bahwa retribusi berhubungan dengan pelayanan maka prinsip manajemen retribusi daerah yang paling utama dalam perbaikan pelayanan, perluasan basis retribusi, pengendalian atas kebocoran yang terjadi pada penerimaan retribusi serta perbaikan administrasi pemungutan retribusi.

Tenaga kerja ialah seseorang yang sedang mencari atau melakukan pekerjaan untuk menghasilkan barang dan jasa pada batasan usia yang ditetapkan oleh Undangundang yang bertujuan untuk memperoleh hasil atau upah untuk kebutuhan hidup sehari-hari. Sebagaimana Undang-Undang Nomor 25 tahun 1997 tentang Ketenagakerjaan maka ditetapkan batas usia kerja penduduk Indonesia menjadi 15 tahun. Partanto (2001) mendefinisikan sebagai penyusunan bersistem atau berkelompok sesuai standar yang ditentukan. Lain halnya pendapat dari Sumarsono (2003), mendefinisikan penyerapan tenaga kerja tergantung dari besar kecilnya permintaan tenaga kerja yang terjadi dan menunjukkan besarnya kemampuan suatu perusahaan dalam menyerap tenaga kerja untuk menghasilkan suatu produk.

Selain itu, Kuznets (Todaro, 2006), berasumsi kenaikan pertumbuhan ekonomi jangka panjang pada negara menyediakan berbagai barang dan jasa publik untuk penduduknya. Menurut Mankiw (2007) menjelaskan pertumbuhan ekonomi 
Ju Kumala Dewi dan Made Kembar Sri Budhi. Analisis Pengaruh Pajak Daerah...

berkaitan dengan proses peningkatan produksi barang dan jasa pada kegiatan ekonomi masyarakat dan diukul melalui PDB berdasarkan harga konstan (PDB Rill), supaya angka pertumbuhan yang dihasilkan ada pertambahan produksi. Teori Ekonomi publik adalah studi tentang kebijakan ekonomi, dengan penekanan khusus pada pajak. Subyek ini meliputi topik-topik yang beragam seperti respon untuk kegagalan pasar karena keberadaan eksternalitas dan penentuan kebijakan keamanan sosial yang optimal. Hal ini perluasan cakupan ekonomi publik dari penekanan awal pada pencairan pendapatan pemerintah untuk semua aspek dari intervensi pemerintah. Banyak peran dari sektor publik yang sering diketahui secara umum antara lain:

1. Peran alokasi membicaran tentang penggunaan sumber daya alam;

2. Peran regulasi yang dikeluarkan pemerintah;

3. Peran redistribusi terkait pemerataan kebijakan;

4. Peran stabilisasi untuk mengontrol fluktuasi secara global.

Peran pajak pada pembangunan dalam upaya penyediaan barang dan jasa publik, yang sifatnya dipaksakan maka akan mempengaruhi perilaku ekonomi masyarakat. Sebab sebagian besar modal pembangunan berasal dari pajak. Serta mekanisme berdampak multiplier effect, employment creation dan terjadi peningkatan output. Dasar dari model pengembangan pertumbuhan sektor publik pada perekonomian mengalami perubahan struktur. Model dari Rostow dan Musgrave menyatakan bahwa pertumbuhan pengeluaran publik yang berhubungan dengan pola pertumbuhan ekonomi dan pembangunan di masyarakat pada tahap-tahap pembangunan ekonomi yang dapat dilihat pada skema berikut: 
1) Tahap Awal $>\%$ investasi pemerintah dan $\%$ investasi swasta

2) Tahap $>$ Peranan investasi swasta sudah semakin membesar, Menengah namun investasi pemerintah tetap diperlukan

3) Tahap Lanjut $>$ Peranan swasta semakin dominan dan aktivitas pemerintah beralih ke social

Hukum Wagner menyatakan bahwa gejala dan prediksi akan berlanjutan, Ia menyatakan perekonomian terjadi bila pendapatan perkapita meningkat dan pengeluaran pemerintah pun akan meningkat yang sering dikenal Law of Expanding State Expenditure, Wagner menjelaskan peran pemerintah semakin besar. Dasar Teori Wagner diantaranya: 1).Pertumbuhan ekonomi mengakibatkan peningkatan kompleksitas; 2). Proses urbanisasi dan meningkatnya ekternalitas; 3). Ia berpendapat barang yang disediakan oleh sektor publik memiliki elatisitas permintaan yang tinggi. Teori ini dikemukakan Peacock dan Wiseman tentang perkembangan pengeluaran pemerintah, Dasar pandangan ini dilihat dari peran pemerintah dalam memperbesar pengeluaran pemerintah yang semakin meningkat namun masyarakat tidak suka dibebankan pajak yang besar hal ini kendala bagi pemerintah dalam menaikkan pajak semena-mena, dapat dilihat pada Gambar 1 ini.

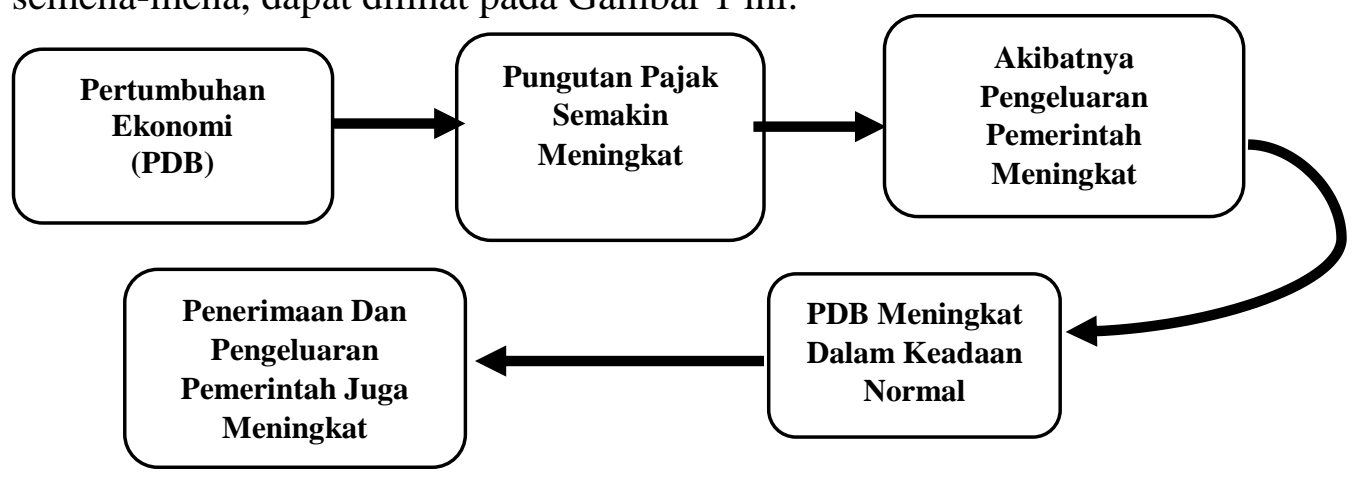

Gambar 1

Alur Hubuangan di Masyarakat 
Ju Kumala Dewi dan Made Kembar Sri Budhi. Analisis Pengaruh Pajak Daerah...

Jika dalam keadaan normal terganggu, dimana adanya gangguan social menyebabkan aktivitas swasta dialihkan apada aktivitas pemerintah disebut efek pengalihan (displacement effect). Saat terjadinya perang maka pemerintah juga harus meminjam ke Negara lain untuk pembiayaannya.

Hukum Baumol mengarah pada teknologi yang digunakan pada sektor publik dengan menggunakan teknologi padat karya pada yang relatif terhadap sektor swasta. Selain itu jenis barang yang diproduksi dalam sektor publik menyebabkan peningkatan produktivitas skala kecil dan hal ini menyebabkan kesulitan melakukan substitusi modal terhadap tenaga kerja. Sedangkan pada Model Efek Ratchet, diasumsikan bahwa publik tidak ingin membayar pajak. Pengeluaran yang lebih tinggi berasal dari pajak, sehingga dengan implikasi umum bagi sebagian yang menolak untuk mendapatkan beberapa manfaat dari pengeluaran. Keseimbangan tingkat pengeluaran pada sektor publik ditentukan oleh keseimbangan antara komponen yang saling bersaing. Ketiadaan perubahan eksogen atau perubahan dalam preferensi, menyebabkan tingkat pengeluaran tetap konstan. Model Ratchet juga berpendapat untuk memungkinkan pemerintah agar meningkatkan pengeluaran dengan persetujuan para pembayar pajak. Hal ini diperlukan untuk memenuhi kebutuhan lain yang lebih penting.

Teori ketenagakerjaan Lewis (1954) mengemukakan bahwa kelebihan pekerja merupakan kesempatan bukan masalah. Kelebihan pekerja dalam satu sektor akan memberikan sumbangan terhadap pertumbuhan output dan menjadi pekerja di sektor 


\section{E-Jurnal Ekonomi dan Bisnis Universitas Udayana 7.6 (2018): 1695-1722}

lain. Ada dua struktur yang penting dalam Negara yang berkembang yaitu sektor kapitalis modern dan sektor subsisten terbelakang (Adioetomo, 2010). Sedangkan Teori Pertumbuhan Ekonomi Solow-Swan (Ekonomi Neo Klasik) adalah salah satu teori pertumbuhan ekonomi. Teori ini berasumsi bahwa pertumbuhan persediaan modal, angkatan kerja serta kemajuan teknologi saling terkait di dalam perekonomian dan pengaruhnya dapat dilihat pada output barang dan jasa di suatu negara secara keseluruhan (Mankiw, 2006). Dan Teori Produk Domestik Regional Bruto yang dikemukakan Boediono (1999), mendefinisikan faktor yang menentukan kenaikan output per kapita dalam jangka panjang dapat dicapai apabila perekonomian bebas dari campur tangan pemerintah dan sepenuhnya diserahkan kepada mekanisme pasar.

\section{HIPOTESIS PENELITIAN}

Hipotesis dalam penelitian ini dirumuskan berikut:

1) Pajak daerah dan retribusi daerah berpengaruh positif dan signifikan terhadap penyerapan tenaga kerja di Kota Palangka Raya Provinsi Kalimantan Tengah.

2) Pajak daerah, retribusi daerah dan penyerapan tenaga kerja berpengaruh positif dan signifikan terhadap pertumbuhan ekonomi di Kota Palangka Raya Provinsi Kalimantan Tengah.

3) Ada pengaruh tidak langsung pajak daerah dan retribusi daerah terhadap pertumbuhan ekonomi melalui penyerapan tenaga kerja di Kota Palangka Raya Provinsi Kalimantan Tengah. 
Ju Kumala Dewi dan Made Kembar Sri Budhi. Analisis Pengaruh Pajak Daerah...

\section{METODE PENELITIAN}

Penelitian ini tergolong jenis penelitian kuantitatif (quantitative research). Sampel penelitian yang digunakan dalam penelitian ini yaitu Kota Palangka Raya. Data sekunder penelitian ini diperoleh di Dinas Pendapatan, data penyerapan tenaga kerja yang diperoleh dari Dinas Tenaga Kerja dan Transmigrasi serta data pertumbuhan ekonomi atas dasar harga konstan 2000 yang diperoleh dari Badan Pusat Statistik di Kota Palangka Raya periode tahun 1996-2016. Pengujian menggunakan teknik analisis jalur dengan aplikasi SPSS 21.

Variabel penelitian menurut Sugiyono (2009), pada dasarnya adalah segala sesuatu yang berbentuk apa saja yang ditetapkan oleh peneliti untuk dipelajari sehingga diperoleh informasi tentang hal tersebut, kemudian ditarik kesimpulannya. Penelitian ini memiliki tiga variabel penelitian, yaitu: (1) variabel eksogen, (2) variabel endogen, dan (3) variabel antara (intervening variable). Variabel eksogen merupakan variabel yang mempengaruhi atau menjadi sebab perubahannya atau timbulnya variabel endogen, sedangkan variabel endogen merupakan variabel yang dipengaruhi atau menjadi akibat karena adanya variabel eksogen. Variabel antara merupakan penyela/antara yang terletak di antara variabel eksogen dan endogen, sehingga variabel eksogen secara tidak langsung dapat mempengaruhi berubahnya variabel endogen. Berikut pada tabel 4.1 disajikan klasifikasi variabel penelitian. 


\section{HASIL PENELITIAN}

Pada hasil analisis data maka dapat disajikan mengenai pengaruh antar variabel yang dapat dilihat pada Gambar 2.

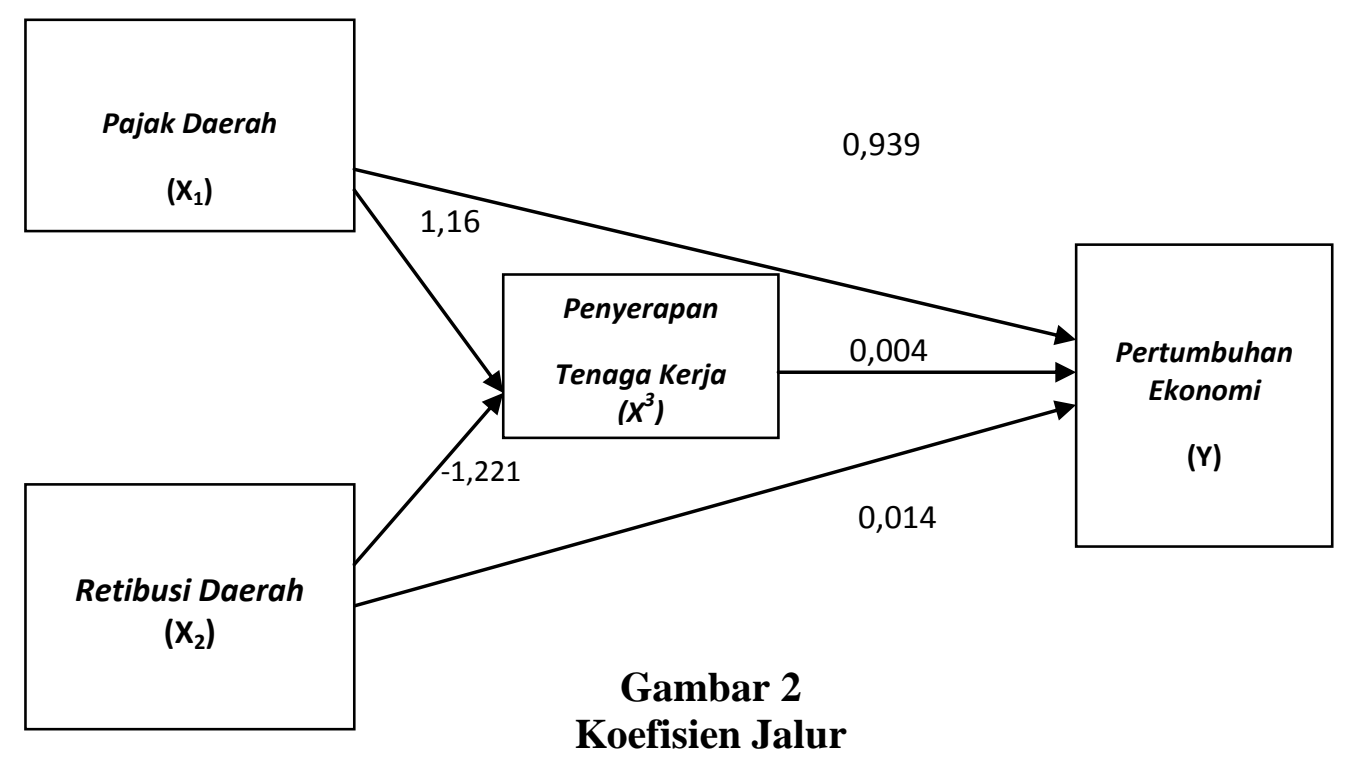

Berdasarkan koefisien jalur di atas maka bentuk hubungan tiap variabel dapat dilihat pada Tabel 4 sebagai berikut:

\section{Tabel 4}

Koefisien Hubungan Langsung, Tidak Langsung, dan Total antar Variabel

\begin{tabular}{ccccccc}
\hline Variabel & \multicolumn{5}{c}{$\mathbf{X}_{\mathbf{3}}$} & \multicolumn{3}{c}{$\mathbf{Y}$} \\
\cline { 2 - 7 } & $\mathbf{P L}$ & $\mathbf{P T L}$ & $\mathbf{P T}$ & $\mathbf{P L}$ & $\mathbf{P T L}$ & PT \\
\hline $\mathbf{X}_{\mathbf{1}}$ & 1,166 & - & 1,166 & 0,935 & 0,004 & 0,939 \\
$\mathbf{X}_{\mathbf{2}}$ & $-1,221$ & - & $-1,221$ & 0,010 & 0,004 & 0,014 \\
$\mathbf{X}_{\mathbf{3}}$ & - & - & - & 0,004 & - & 0,004 \\
\hline
\end{tabular}

Sumber: Lampiran 2 dan Lampiran 3 
Ju Kumala Dewi dan Made Kembar Sri Budhi. Analisis Pengaruh Pajak Daerah...

\section{Keterangan:}

$$
\begin{array}{ll}
\text { PL } & =\text { Pengaruh Langsung } \\
\text { PTL } & =\text { Pengaruh Tidak Langsung } \\
\text { PT } & =\text { Pengaruh Total }
\end{array}
$$

Berdasarkan Tabel 4 dapat dijelaskan pengaruh langsung pajak daerah $\left(\mathrm{X}_{1}\right)$ pada tenaga kerja $\left(\mathrm{X}_{3}\right)$ adalah 1,166 maka pengaruh totalnya sebesar 1,166 . Sedangkan pengaruh langsung retribusi daerah $\left(\mathrm{X}_{2}\right)$ pada tenaga kerja $\left(\mathrm{X}_{3}\right)$ sebesar -1,221 dan untuk pengaruh totalnya sebesar $-1,221$. Pengaruh langsung pajak daerah $\left(\mathrm{X}_{1}\right)$ pada variabel nilai Pertumbuhan Ekonomi (Y) adalah 0,935. Pengaruh tidak langsung pajak daerah $\left(\mathrm{X}_{1}\right)$ pada pertumbuhan ekonomi yang melalui tenaga kerja $\left(\mathrm{X}_{3}\right)$ diperoleh dari (p1 x p5) yaitu 1,166 x 0,004 =0,004. Sehingga pengaruh total untuk pajak daerah $\left(\mathrm{X}_{1}\right)$ pada pertumbuhan ekonomi adalah $0,935+0,004=0,939$ Pengaruh langsung retribusi daerah $\left(\mathrm{X}_{2}\right)$ pada pertumbuhan ekonomi $(\mathrm{Y})$ adalah 0,010. Pengaruh tidak langsung retribusi daerah $\left(\mathrm{X}_{2}\right)$ pada pertumbuhan ekonomi (Y) melalui tenaga kerja $\left(\mathrm{X}_{3}\right)$ diperoleh dari $(\mathrm{p} 2 \times \mathrm{p} 5)$ yaitu sebesar $-1,221 \times 0,004=-$ 0,004. Sehingga pengaruh total retribusi daerah $\left(\mathrm{X}_{2}\right)$ terhadap pertumbuhan ekonomi adalah $0,010+0,004=0,014$. Sedangkan untuk Pengaruh langsung tenaga kerja $\left(\mathrm{X}_{3}\right)$ terhadap pertumbuhan ekonomi (Y) adalah 0,004 dan untuk pengaruh totalnya tetap sebesar 0,004 . 


\section{PEMBAHASAN}

\section{1) Pengaruh Pajak Daerah pada Tenaga Kerja}

Dari hasil penelitian diperoleh kesimpulan bahwa bahwa pajak daerah berpengaruh dan signifikan tenaga kerja pada Kota Palangka Raya Provinsi Kalimantan Tengah selama tahun 1996-2016. Hal ini menunjukkan hubungan searah antara pajak daerah dengan tenaga kerja pada Kota Palangka Raya, hal ini dapat menjadi pendorong dan membuka kesempatan kerja bagi masyarakat yang membutuhkan pekerjaan, yang akhirnya akan meningkatkan pendapatan masyarakat. Pajak Daerah menunjukkan tingkat kemandirian suatu daerah, karena pajak daerah berasal dari daerah itu sendiri sehingga dapat membiayai pembangunan daerahnya. Pada hasil penelitian ini, diperoleh bahwa pajak daerah berpengaruh secara positif dan signifikan terhadap tenaga kerja dengan tingkat signifikansi 5\%. Nilai koefisien yang diperoleh sebesar 0.027 yang berarti bahwa apabila pajak daerah meningkat 1 Juta Rupiah maka akan meningkatkan tenaga kerja sebesar 0.027 Orang. Hal tersebut sesuai dengan hipotesis bahwa pajak daerah berpengaruh signifikan terhadap tenaga kerja. Dengan adanya peningkatan pajak daerah melalui partisipasi masyarakat yang turut serta dalam membayar pajak daerah dan aktifnya pemerintah daerah menarik pajak daerah maka akan meningkatkan penerimaan pajak daerah, yang nantinya digunakan untuk kegiatan produksi sehingga akan menghasilkan output berupa barang maupun jasa, sehingga akan meningkatkan Pertumbuhan ekonomi. Penelitian ini sejalan dengan Teori Solow-Swan, dimana pertumbuhan ekonomi tergantung pada penyediaan faktor-faktor produksi, salah satunya adalah akumulasi 
Ju Kumala Dewi dan Made Kembar Sri Budhi. Analisis Pengaruh Pajak Daerah...

modal dalam hal ini adalah pajak daerah. Berdasarkan teori tersebut diketahui bahwa variabel input khususnya pajak daerah memiliki peranan penting karena akan menentukan besarnya jumlah output yang dihasilkan. Hal ini disebabkan pajak daerah digunakan sebagai modal untuk melakukan pembangunan sehingga akan merangsang kegiatan ekonomi dan akan menghasilkan output berupa barang maupun jasa yang pada akhirnya akan meningkatkan pertumbuhan ekonomi. Penelitian ini juga sejalan dengan penelitian yang dilakukan Andres Rodriguez dan Anne Kroijer (2009) dan Amelia (2010) bahwa pajak daerah berpengaruh positif dan signifikan terhadap Pertumbuhan ekonomi.

Penelitian ini juga sesuai dengan penelitian yang dilakukan oleh Purwanti (2009) yang menyatakan bahwa keberhasilan suatu pemerintahan salah satunya dilihat dari sejauh apa pemerintah tersebut berhasil menciptakan lapangan kerja bagi masyarakatnya, dengan penciptaan lapangan kerja yang tinggi akan berdampak pada peningkatan daya beli masyarakat sehingga pada akhirnya kesejahteraan masyarakat akan meningkat dan dapat menyerap tenaga kerja sehingga dapat mengurangi tingkat pengangguran di suatu daerah.

\section{2) Pengaruh Retribusi Daerah pada Tenaga Kerja}

Dari hasil penelitian diperoleh kesimpulan bahwa bahwa retribusi daerah berpengaruh dan signifikan tenaga kerja pada Kota Palangka Raya Provinsi Kalimantan Tengah selama tahun 1996-2016. Hal ini menunjukkan hubungan searah 


\section{E-Jurnal Ekonomi dan Bisnis Universitas Udayana 7.6 (2018): 1695-1722}

antara retribusi daerah dengan tenaga kerja pada Kota Palangka Raya. Dalam penelitian ini, retribusi daerah berpengaruh positif dan signifikan terhadap pertumbuhan ekonomi dengan tingkat signifikansi 5\%. Nilai koefisien retribusi daerah sebesar 0.021 yang berarti bahwa apabila retribusi daerah meningkat 1 Juta Rupiah, maka akan meningkatkan Tenaga Kerja sebesar 0.021 Orang. Hal ini sesuai dengan hipotesis pertama bahwa retribusi daerah berpengaruh signifikan terhadap Tenaga Kerja. Dengan adanya peningkatan retribusi daerah dan tegasnya pemerintah daerah setempat menarik retribusi daerah, maka akan meningkatkan pendapatan di daerah tersebut. Dengan meningkatnya pendapatan asli daerah yang berasal dari daerah itu sendiri yang dapat berperan dalam meningkatkan pembiayaan pembangunan dan meningkatkan kegiatan ekonomi. Penelitian ini sejalan dengan Teori Solow-Swan, dimana pertumbuhan ekonomi tergantung pada penyediaan faktor-faktor produksi, salah satunya adalah akumulasi modal dalam hal ini adalah retribusi daerah. Berdasarkan teori tersebut diketahui bahwa variabel input khususnya retribusi daerah memiliki peran penting dalam menentukan besarnya jumlah output yang dihasilkan. Hal ini disebabkan retribusi daerah digunakan sebagai modal untuk melakukan pembangunan yang akan merangsang kegiatan ekonomi dan secara tidak langsung menambah jumlah tenaga kerja yang bekerja pada proses pembangunan yang berlangsung oleh pemerintah daerah. Penelitian ini juga sejalan dengan penelitian yang dilakukan Amelia (2008) dan Lucky (2011). 
Ju Kumala Dewi dan Made Kembar Sri Budhi. Analisis Pengaruh Pajak Daerah...

\section{3) Pengaruh Pajak Daerah pada Pertumbuhan Ekonomi}

Pengaruh pajak daerah pada pertumbuhan ekonomi di Kota Palangka Raya. Dalam penelitian ini, pajak daerah berpengaruh positif dan signifikan terhadap pertumbuhan ekonomi dengan tingkat signifikansi 5\%. Nilai koefisien pajak daerah sebesar 0.001 yang berarti bahwa apabila pajak daerah meningkat 1 Juta Rupiah maka akan meningkatkan Tenaga Kerja sebesar 0.001 Orang. Hal ini sesuai hipotesis kedua bahwa pajak daerah berpengaruh signifikan terhadap pertumbuhan ekonomi. Dengan adanya PAD khususnya dari sektor pajak daerah maka perekonomian dan pembangunan di suatu daerah akan berjalan dengan lancar serta dapat mendorong pertumbuhan sektor swasta dan rumah tangga dalam mengalokasikan sumber daya yang ada di suatu daerah yang akan menyebabkan makin meningkatnya Pertumbuhan Ekonomi. Hal ini sejalan dengan penelitian Hidayat dan Nalle (2017) yang menunjukkan variabel belanja pemerintah, tenaga kerja dan PAD berpengaruh secara positif dan signifikan terhadap pertumbuhan ekonomi.

\section{4) Pengaruh Retribusi Daerah pada Pertumbuhan Ekonomi}

Dari hasil penelitian diperoleh kesimpulan bahwa retribusi daerah tidak berpengaruh terhadap pertumbuhan ekonomi pada Kota Palangka Raya Provinsi Kalimantan Tengah selama tahun 1996-2016. Dalam penelitian ini, nilai koefisien retribusi daerah sebesar 0.966 yang berarti bahwa apabila retribusi daerah 1 Juta Rupiah, maka akan meningkatkan pertumbuhan ekonomi sebesar 0.966 Juta Rupiah. 


\section{E-Jurnal Ekonomi dan Bisnis Universitas Udayana 7.6 (2018): 1695-1722}

Hal ini sejalan dengan penelitian yang dilakukan oleh Handayani (2015) bahwa retribusi daerah tidak berpengaruh terhadap pertumbuhan ekonomi.

\section{5) Pengaruh Tenaga Kerja pada Pertumbuhan Ekonomi}

Dari hasil penelitian diperoleh kesimpulan bahwa tenaga kerja tidak berpengaruh dan nonsignifikan terhadap Pertumbuhan ekonomi pada Kota Palangka Raya Provinsi Kalimantan Tengah selama tahun 1996-2016. Dalam penelitian ini, tenaga kerja tidak berpengaruh terhadap pertumbuhan ekonomi dengan tingkat signifikansi 5\%. Nilai koefisien tenaga kerja sebesar 0.964 yang berarti bahwa apabila tenaga kerja meningkat 1 Orang, maka akan meningkatkan pertumbuhan ekonomi sebesar 0.964 Juta Rupiah, maka dapat dikatakan bahwa kesempatan kerja tidak dapat memediasi pengaruh tenaga kerja terhadap pertumbuhan ekonomi di Kota Palangka Raya, karena tenaga kerja yang terserap tidak didukung dengan sumber daya manusia yang ada dalam hal ini disebabkan oleh masih kurangnya pendidikan dan keterampilan yang didapat oleh tenaga kerja, teknologi yang mendukung dan masih banyaknya pengangguran yang terselubung pada wilayah pedesaan yang kurang mendapat pelatihan pekerjaan dari pemerintah daerah. Hal ini sejalan dengan penelitian yang dilakukan oleh Bhinadi (2003), retribusi daerah tidak berpengaruh terhadap pertumbuhan ekonomi. 
Ju Kumala Dewi dan Made Kembar Sri Budhi. Analisis Pengaruh Pajak Daerah...

\section{SIMPULAN DAN SARAN}

Adapun simpulan yang dapat diambil dari hasil uji hipotesis penelitian ini yaitu: (1) Pajak daerah dan retribusi daerah berpengaruh positif dan signifikan terhadap penyerapan tenaga kerja di Kota Palangka Raya Provinsi Kalimantan Tengah, (2) Pajak daerah berpengaruh positif dan signifikan terhadap pertumbuhan ekonomi, retribusi daerah tidak berpengaruh terhadap pertumbuhan ekonomi dan tenaga kerja tidak berpengaruh terhadap Pertumbuhan Ekonomi di Kota Palangka Raya Provinsi Kalimantan Tengah, dan (3) Hasil Pengujian pengaruh tidak langsung yang dilakukan antara pajak daerah dan retribusi daerah terhadap pertumbuhan ekonomi melalui tenaga kerja tidak mampu memediasi variabel pajak daerah dan retribusi daerah pada pertumbuhan ekonomi.

Pemerintah sebagai pembuat perencanaan yang rasional dan mencari sumber pendanaan baru pada sub sektor penerimaan daerah agar dapat digali untuk menambah anggaran pembangunan yang efektif, efisien dan ekonomis guna mensejahterakan masyarakat. Upaya yang dapat dilakukan pemerintahan daerah dalam peningkatan pertumbuhan ekonomi dengan cara meningkatkan pengeluaran rutin dan pengeluaran pembangunan dan mengalokasikannya secara baik dan tepat sasaran guna pemerataan pembangunan dan program pemberdayaan masyarakat miskin yang produktif dan memiliki penghasilan yang lebih baik untuk meningkatkan kesejahteraan masyarakat.

Usaha yang dapat dilakukan pemerintah daerah dalam meningkatkan sumber daya manusia yang berkualitas diantaranya melalui program kewirausahaan dan kursus 


\section{E-Jurnal Ekonomi dan Bisnis Universitas Udayana 7.6 (2018): 1695-1722}

keterampilan, pelatihan, program magang keluar daerah dengan adanya program ini diharapkan adanya peningkatan kualitas bagi angkatan kerja dan Sumber Daya Manusia yang unggul agar dapat terserap di dalam lapangan kerja dan sektor ekonomi yang tersedia.

\section{REFERENSI}

Ali, Fauzan. 2015. Service Quality As A Determinant of Consumer Satisfaction and Resulting Behavioural Intention: A SEM Approach Towards Malaysian Resort Hotel, Tourism Original Scientific Paper, 63 (1): 37-51.

Adioetomo, S.M., Burhan, L. Yunus, N., 2010. 100 Tahun Demografi Indonesia, mengubah Nasib Menjadi Harapan. Cetakan Kedua. Jakarta: BKKBN dan Lembaga Demografi Fakultas Ekonomi UI.

Arsyad, Lincolin. 2004. Ekonomi Pembangunan. Edisi Keempat. Yogyakarta: STIE YKPN.

A.Partanto, Pius dan Al Barry, M. Dahlan. 2001. Kamus Ilmiah Populer. Surabaya: Arkola.

Artur, Lewis. 1954. Economic Development With Unlimited Supplies and Labour Manchaster School. England.

Bernard L.Tanya, 2011. Politik Hukum, Agenda Kepentingan Bersama. Yogyakarta : Genta Publishing.

B. Ilyas Wirawan dan Richard Burton. 2007. Hukum Pajak. Jakarta: Salemba Empat.

Bahl, 2002. Mengevaluasi Pelaksanaan Desentralisasi Fiskal di Indonesia. Yogyakarta: UGM.

Boediono. 1999. Teori Pertumbuhan Ekonomi. Yogyakarta: BPFE.

Chairil Nizar. 2011. Agregat Halus Kasar, diakses di http://www.ilmusipil.com/agregat-halus-kasar 22 Agustus 15. Pukul 11.37.

Chigbu, Emmanuel Ezeji \& Njoku, Charles Odinakachi. 2015. Taxation and the Nigerian Economy: (1994-2012). Nigeria: Management Studies and Economic Systems (MSES), 2 (2), 111-128, Autumn 2015, ZARSMI. 
Ju Kumala Dewi dan Made Kembar Sri Budhi. Analisis Pengaruh Pajak Daerah...

Darwanto dan Yulia Yustikasari, 2006. Pengaruh Pertumbuhan Ekonomi, PAD dan Dana Alokasi Umum terhadap Pengalokasian Anggaran Belanja Modal. Makassar:Simposium Nasional Akuntansi X.

Direktorat Jenderal Perimbangan Keuangan Pusat dan Daerah Departemen Keuangan Republik Indonesia.2004. Tinjauan Hubungan Keuangan Pusat dan Daerah 20012003. Jakarta.

Dwiyanto, Agus, dkk.2006. Reformasi Birokrasi Publik Di Indonesia. Yogyakarta: UGM Press.

Erly, Suandy. 2005. Hukum Pajak. Edisi Ketiga. Jakarta: Salemba Empat.

Ferdinand, Augusty.2002. Structural Equation Modelling dalam Penelitian Manajemen. Semarang : FE UNDIP.

Ghozali, Imam. 2009. Aplikasi Analisis Multivariate dengan Program SPSS. Semarang: Badan Penerbit Universitas Diponegoro.

Hair, et al.2006. Multivariate Data Analisys. Sixth Edition. New Jersey: Pearson Education.

Kuncoro, Haryo.2004. Pengaruh Transfer Antar Pemerintah pada Kinerja Fiskal Pemerintah Daerah Kota dan Kabupaten di Indonesia. Jurnal Ekonomi Pembangunan. Vol.9 No.1 : 47-63.

Lucky, D. 2011. Analisis Pengaruh Variabel Penerimaan Daerah Terhadap Pertumbuhan Ekonomi Daerah di Era Desentralisasi: Studi Kasus Kabupaten/Kota Wilayah Keresidenan Malang Tahun 2004-2009. (Skripsi). Malang: Universitas Brawijaya.

Mahmudi. 2010. Manajemen Kinerja Sektor Publik. UPP STIM YKPN: Yogyakarta.

Mariana, Suyana Utama, Made, Purbadharmaja, Ida Bagus. 2014. Pengaruh Pertumbuhan Investasi, Pertumbuhan Penyerapan Tenaga Kerja terhadap Pertumbuhan Ekonomi dan Perubahan Struktur Ekonomi di Provinsi Bali. E-Jurnal Ekonomi dan Bisnis Universitas Udayana Vol. 3, No.6 (2014): 330-344. Denpasar: Fakultas Ekonomi Universitas Udayana.

Mahmudi. 2010. Manajemen Kinerja Sektor Publik. UPP STIM YKPN: Yogyakarta. Myles, Garteh. 1995. Public Economics. New York: Cambridge University Press. Mangkoesoebroto, Guritno.1991. Ekonomi Publik. Edisi II. Yogyakarta: BPFE. Mangkusubroto, Guritno.1997. Ekonomi Publik. Yogyakarta : BPFE. 
Mankiw, N. Gregory,2006. Principles of Economics. Pengantar Ekonomi Makro. Edisi Ketiga.Alih Bahasa Chriswan Sungkono. Jakarta: Salemba Empat.

Mankiw, N. Gregory, 2007. Makroekonomi. Edisi Keenam. Jakarta: Erlangga.

Manullang, M. 1998. Manajemen Personalia. Jakarta: Ghalia Indonesia.

Mardiasmo. 2004. Otonomi dan Manajemen Keuangan Daerah. Edisi Kedua. Yogyakarta: Andi.

Mardiasmo. 2006. Perwujudan Transparansi dan Akuntabilitas Publik Melalui Akuntansi Sektor Publik: Suatu Sarana Good Governance. Jurnal Akuntansi Pemerintahan, 2: 1. (1-17).

Putri, Tria Dessi, dkk. 2013. Analisis Pengaruh Pendapatan Asli Daerah Dan Pengeluaran Pemerintah Terhadap Perkembangan Ekonomi Provinsi Lampung Tahun 2000-2013. Bandar Lampung: Universitas Lampung.

Paton, G.W.tt. Jurisprudence, diterjemahkan oleh Arief, S.Surabaya : Pustaka Tinta Mas.

Prasetya, Ferry. 2012. Modul Ekonomi Publik Bagian I, Teori Sektor Publik. Fakultas Ekonomi dan Bisnis Universitas Brawijaya : Malang.

Ridwan dan Kuncoro, E.A. 2008. Cara Menggunakan dan Memakai Analisis Jalur. Alfabeta, Bandung.

Sadono Sukirno, 1985. Ekonomi Pembangunan. Jakarta: LPEF-UI Bima Grafika.

Siahaan, P. Marihot. 2005. Pajak Daerah dan Retribusi Daerah. Jakarta: Rajagrafindo Persada.

Subri, Mulyadi. 2003. Ekonomi Sumber Daya Manusia. Jakarta: Raja Grafindo Persada.

Sumarsono, Sonny. 2003. Ekonomi Manajemen Sumber Daya Manusia Dan Ketenagakerjaan. Yogyakarta: Graha Ilmu.

Sun'an Muammil \& Endang Astuti.2010. Analisis Investasi, Pengeluaran Pemerintah dan Pertumbuhan Ekonomi Terhadap Kesempatan Kerja Di Provinsi Nusa Tenggara Barat. Vol. 1 No. 1: Iqtishodunia.

Suparmoko, M. 2002. Ekonomi Publik, Untuk Keuangan dan Pembangunan Daerah. Yogyakarta: Andi.

Suryana.2000. Ekonomi Pembangunan: Problematika dan Pendekatan. Edisi I Jakarta: Salemba Empat. 
Ju Kumala Dewi dan Made Kembar Sri Budhi. Analisis Pengaruh Pajak Daerah...

Sutrisno, Hadi. 1984. Bimbingan Menulis Skripsi Thesis : Jilid Pertama. Yogyakarta: Yayasan Penerbitan Fakultas Psikologi UGM.

Tim Penyusun. 2015. Buku Pedoman Penulisan Usulan Penelitian, Tesis dan Disertasi. Program Pascasarjana Universitas Udayana. Denpasar.

Todaro, Michael dan Smith, Stephen, C. 2000. Pembangunan Ekonomi. Jakarta: Penerbit Erlangga.

Todaro, Michael dan Smith, Stephen, C. 2006. Pembangunan Ekonomi. Jakarta: Penerbit Erlangga.

Utama, Made Suyana. 2012. Aplikasi Analisis Kuantitatif (Edisi Kedua). Modul Statistika Bisnis. Program Magister Ilmu Ekonomi. Program Pascasarjana. Fakultas Ekonomi Universitas Udayana. Denpasar: Universitas Udayana.

Vedder, Richard. 2001. Taxes and Economy Growth. Ohio University.

Peraturan Pemerintah Daerah Nomor 65 Tahun 2001 Tentang Pajak Daerah dan Retribusi Daerah.

Undang-Undang Nomor 13 Tahun 2003 Tentang Ketenagakerjaan.

Undang-Undang Nomor 23 Tahun 2014 Tentang Pemerintahan Daerah.

Undang-Undang Nomor 25 Tahun 1997 Tentang Ketenagakerjaan.

Undang-Undang Nomor 28 Tahun 2009 Tentang Pajak Daerah Dan Retribusi Daerah.

Undang-Undang Republik Indonesia Nomor 18 Tahun 1997 Tentang Pajak Daerah dan Retribusi Daerah.

Undang-Undang Republik Indonesia Nomor 32 Tahun 2004 Tentang Pemerintahan Daerah.

Undang-Undang Republik Indonesia Nomor 32 Tahun 2004 Tentang Perimbangan Keuangan Antara Pemerintah Pusat Dan Daerah.

Undang-Undang Republik Indonesia Nomor 34 Tahun 2000 Tentang Pemerintahan Daerah, Pajak Daerah dan Retribusi Daerah.

Undang-Undang RI Nomor 13 Tahun 2003 Tentang Ketenagakerjaan. 